\title{
Foucault e a influência teórica nas ciências humanas
}

\section{O legado de Foucault.}

ALVAREZ, Marcos César; MISKOLCI, Richard; SCAVONE, Lucila (Orgs.).

São Paulo: Ed. Unesp, 2006. 330 p.

Marcos César Alvarez, Richard Miskolci e Lucila Scavone organizam a coletânea $O$ legado de Foucault. O livro teve origem a partir do seminário realizado no ano de 2004 , na Faculdade de Ciências e Letras da Unesp, em homenagem a Michel Foucault nos 20 anos de sua morte, ' que teve como principal objetivo o debate a respeito da influência teórica do pensamento de Michel Foucault às ciências humanas contemporâneas, com ênfase em disciplinas como Sociologia, História, Filosofia, Política e Antropologia.

A coletânea inicia com o texto de Philippe Artières, intitulado"Entrelinhas: ler os arquivos de Michel Foucault". O historiador responsável pelo centro que leva o nome do filósofo, em Paris, alerta que pesquisadores não encontraram nesses arquivos manuscritos, dados biográficos ou textos inéditos, tampouco relíquias, mas, conforme afirma Artières, são os "arquivos de um leitor". Afirma que os leitores encontrarão milhares de notas de Foucault que possibilitam realizar a cartografia do trabalho foucaultiano.

Em "Engajamentos e resistências", José Carlos Bruni debate o conceito de sujeito. Segundo Bruni, Foucault não pretendeu destruir o sujeito, mas trabalhou com os conceitos de sujeito sob os enfoques do marxismo, da fenomenologia e do positivismo. O filósofo apresenta as tecnologias de sujeição e trata do sujeito assujeitado, silenciado e oprimido, entretanto não apresenta as formas de libertação desses sujeitos.

Marcos César Alvarez discute as posições políticas adotadas por Michel Foucault ao longo de sua trajetória, principalmente sua participação no Groupe d'Information sur les Prisons (GIP), que possibilitou a Foucault alternar sua produção teórica com a prática. Durante sua participação no GIP, Foucault não falou em nome dos presos, mas pretendeu criar espaço para que estes falassem por si próprios. Procurou ouvir as reivindicações dos presos chamando atenção para os problemas enfrentados pelos prisioneiros na época. Em Vigiar e punir, Foucault mostra como o poder disciplinar irá modelar os corpos, criando corpos dóceis, adestrados a partir de uma vigilância constante, não somente nas prisões, mas em toda a sociedade. A partir de sua participação no GIP, Foucault aponta que "as práticas prisionais - e o poder disciplinar a elas associado - e que deveriam ser tomadas como intoleráveis na sociedade" (p. 57).

Em "Feminismos", quatro artigos procuram apresentar as similaridades do pensamento de Foucault com a insurgência do movimento feminista ${ }^{2}$ de segunda onda. ${ }^{3} \mathrm{O}$ capítulo inicia com o texto não inédito da historiadora francesa Michèlle Perrot, que, por ser contemporânea do filósofo, enriquece a coletânea. Afirma que a história das mulheres não é uma preocupação inicial do filósofo, mas há vários estudos que relacionam as mulheres e as diferenças dos sexos com os pensamentos de Foucault. Conforme a autora, as feministas são contrárias ao androcentrismo de Foucault, entretanto, 0 pensador oportunizou por meio de sua "caixa de ferramentas" a discussão de questões importantes para a crítica feminista, como o poder, o corpo, as resistências e a tecnologia de si. Ao criticar as identidades sexuais, Foucault se afasta do pensamento feminista, mas essas relações se estreitam quando o pensador trata da família como "instância da regulamentação da moral e da razão" (p. 67). Seja por afirmar que a maternidade não é o fim das mulheres, por discutir acerca do estupro e do incesto ou por possibilitar a escrita da história por meio de novas fontes, que fizeram emergir novos sujeitos históricos, é visível a contribuição de Foucault para a história das mulheres.

Lucila Scavone aponta o caráter inovador das lutas feministas contemporâneas ao filósofo e o fato de serem consideradas lutas cotidianas que se insurgem contra $\circ$ poder. Foucault, apesar de não ter se debruçado sobre os movimentos feministas, enquadrou-os como lutas de resistência e criticou "os movimentos 
fundamentados na identidade sexual, pelo risco de criarem outro assujeitamento" (p. 86). A possibilidade de criação de novos espaços de liberdade e o questionamento dos modelos de feminilidade são algumas das possibilidades de intersecção entre os feminismos e Foucault, conforme explica Margareth Rago, em "Foucault, a subjetividade e as heterotopias feministas".

Criticando a história positivista e universalizante, Tania Swain propõe que o encontro dos feminismos e do pensamento de Michel Foucault está na proposta de um novo modo de se fazer ciência e história, trazendo a crítica às verdades científicas, que permite dar visibilidade aos novos sujeitos históricos. Propõe de uma forma ímpar articular a crítica e a epistemologia feminista ao pensamento de Foucault.

O capítulo sobre amizade, corpo e estética da existência inicia com o artigo de Hélio Rebello Cardoso Jr., que faz uma relação entre os pensamentos de Foucault, Deleuze e Guatarri sobre a amizade na filosofia platônica. Destaca o estudo de Foucault sobre o amor entre o homem maduro e o jovem, apresentando essas relações, por vezes, conflituosas, marcadas por sujeitos que ocupam posições ativas e passivas. Richard Miskolci traça um paralelo entre as vidas de Oscar Wilde e Michel Foucault, aproximando o modo de viver transgressor dos autores e afirmando que ambos pretendiam desenvolver uma ética da existência. Segundo Foucault, os pilares da estética seriam a política da amizade e a intensificação dos prazeres. Ademais tinha em comum o fato de serem homossexuais, o que, segundo Foucault, vai além do ato sexual e se traduz em um estilo de vida. Finalizando o capítulo, o artigo de Carlos José Martins analisa o conceito de biopoder como uma força que age sobre os corpos e as subjetividades e que pretende o controle, opondo-se a qualquer forma de resistência. Para tal análise, Martins se utiliza das discussões de Foucault a respeito do poder pastoral, do higienismo, do eugenismo e da sexualidade.

O quinto capítulo do livro, intitulado "Direito, violência e controle social", inicia com o artigo de Sérgio Odorno, que traz as contribuições do filósofo que discute não somente o direito e o poder mas também os micropoderes que se investem sobre os corpos dos sujeitos adestrandoos. Apresenta também o fato de o sexo estar em discussão a partir do século XVIII, com enfoque repressivo sobre a sexualidade, não somente do casal, mas das crianças, dos loucos, dos criminosos etc. Andrei Koerner discute o direito, posto na forma da lei pelo Estado, que convive com organizações privadas e que por meio de dispositivos não jurídicos de controle de vigilância e comportamentos impõe formas não estatais de regulação dos sujeitos. Luiz Antônio Francisco de Souza traz suas reflexões sobre a tecnologia de vigilância eletrônica e os mecanismos disciplinares clássicos; uma obsessão crescente por segurança que se traduz no aumento das vigilâncias e na disseminação dos dispositivos disciplinares. Para a manutenção do controle sob a sociedade, a gestão da população se dá por meio da segurança, da seguridade e do seguro.

O artigo de Marcos Nalli discute questões filosóficas referentes a Michel Foucault, principalmente a loucura, a psicopatologia e a psiquiatria. Ricardo Monteagudo encerra o livro analisando Michel Foucault e o anti-hegelianismo no final dos anos 1950.

A coletânea aborda temas variados que foram estudados pelo filósofo, ressaltando a atualidade de suas discussões. Como em outros livros originados de simpósios realizados para homenagear Foucault, ${ }^{4}$ o livro traz contribuições importantes sobre os desdobramentos possíveis a partir dos escritos de Michel Foucault, entretanto, não exaure o debate e as possibilidades de intersecções entre o pensamento do filósofo e as ciências humanas.

\section{Notas}

${ }^{1}$ Michel Foucault perspectivas e Figuras de Foucault são livros originados a partir de seminários que homenagearam Michel Foucault nos 20 anos de sua morte, realizados na Universidade Federal de Santa Catarina (UFSC) e na Universidade Estadual de Campinas (Unicamp), respectivamente, no ano de 2004.

${ }^{2}$ Ao afirmar que o sexo é político, pois contém também relações de poder, o feminismo rompe com os modelos políticos tradicionais, que atribuem uma neutralidade ao espaço individual e que definem como política unicamente a esfera pública, 'objetiva'. Desta forma, o discurso feminista, ao apontar para o caráter também subjetivo da opressão e para os aspectos emocionais da consciência, revela os laços existentes entre as relações interpessoais e a organização política pública (Branca Moreira ALVES e Jaqueline PITANGUY, 1991).

${ }^{3}$ As reivindicações feministas imbuíam-se do desejo de transformação que ocorreu a partir do movimento de 1968. Nesse contexto de efervescência mundial, um novo feminismo surge em diversos países, sendo as suas propostas muito similares umas às outras. Sobre essas experiências ver Carla Bassanezi PINSKY e Jaime PINSKY, 2003.

${ }^{4}$ Renato RIBEIRO, 1985. 


\section{Referências bibliográficas}

ALVES, Branca Moreira; PITANGUY, Jaqueline. $O$ que é feminismo. 8. ed. São Paulo: Brasiliense, 1991.

FALCÃO, Luís Felipe; SOUZA, Pedro (Orgs.). Michel Foucault perspectivas. Rio de Janeiro: Achiamé, 2005. 142 p.

PINSKY, Carla Bassanezi; PINSKY, Jaime. História da cidadania. São Paulo: Contexto, 2003.
RAGO, Margareth; VEIGA-NETO, Alfredo (Orgs.). Figuras de Foucault. Belo Horizonte: Autêntica, 2006. 295 p.

RIBEIRO, Renato (Org.). Recordar Foucault. São Paulo: Brasiliense, 1985.

Claudia Regina Nichnig Universidade Federal de Santa Catarina 